\title{
Assessing the impacts of climate change on cereal production in Bangladesh: evidence from ARDL modeling approach
}

\author{
Abbas Ali Chandio and Yuansheng Jiang \\ College of Economics, Sichuan Agricultural University - Chengdu Campus, \\ Chengdu, China \\ Tehreem Fatima \\ Asian Demographic Research Institute, Shanghai University, Shanghai, China \\ Fayyaz Ahmad \\ School of Economics, Lanzhou University, Lanzhou, China \\ Munir Ahmad \\ School of Economics, Zhejiang University, Hangzhou, China, and
}

Jiajia Li

College of Economics, Sichuan Agricultural University - Chengdu Campus, Chengdu, China

\begin{abstract}
Purpose - This study aims to examine the impacts of climate change (CC), measured average annual rainfall, average annual temperature and carbon dioxide $\left(\mathrm{CO}_{2} \mathrm{e}\right)$ on cereal production (CPD) in Bangladesh by using the annual dataset from 1988-2014, with the incorporation of cereal cropped area $(\mathrm{CCA})$, financial development (FD), energy consumption (EC) and rural labor force as important determinants of CPD.

Design/methodology/approach - This study used an auto-regressive distributive lag (ARDL) model and several econometric approaches to validate the long- and short-term cointegration and the causality directions, respectively, of the scrutinized variables.

Findings - Results of the bounds testing approach confirmed the stable long-term connections among the underlying variables. The estimates of the ARDL model indicated that rainfall improves CPD in the short-and long-term. However, $\mathrm{CO}_{2} \mathrm{e}$ has a significantly negative impact on $\mathrm{CPD}$ both in the short-and long-term. Results further showed that temperature has an adverse effect on CPD in the short-term. Among other determinants, CCA, FD and EC have significantly positive impacts on CPD in both cases. The outcomes of Granger

(C) Abbas Ali Chandio, Yuansheng Jiang, Tehreem Fatima, Fayyaz Ahmad, Munir Ahmad and Jiajia Li. Published by Emerald Publishing Limited. This article is published under the Creative Commons Attribution (CC BY 4.0) licence. Anyone may reproduce, distribute, translate and create derivative works of this article (for both commercial and non-commercial purposes), subject to full attribution to the original publication and authors. The full terms of this licence may be seen at http:// creativecommons.org/licences/by/4.0/legalcode

Funding: This research was financed and supported by the Soft Science Research Project of Sichuan Provincial Department of Science and Technology, Project code: 2021JDR0169, "Research on measurement of agricultural weather risk and development path of inclusive weather finance."
\end{abstract}

Impacts of climate change on cereal production

Received 22 October 2020 Revised 5 April 2021 6 July 2021 19 July 2021 Accepted 20 July 2021
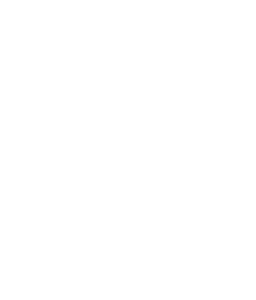
IJCCSM 14,2

causality indicated that a significant two-way causal association is running from all variables to CPD except temperature and rainfall. The connection between $\mathrm{CPD}$ and temperature is unidirectional, showing that CPD is influenced by temperature. All other variables also have a valid and significant causal link among each other. Additionally, the findings of variance decomposition suggest that results are robust, and all these factors have a significant influence on CPD in Bangladesh.

Research limitations/implications - These findings have important policy implications for Bangladesh and other developing countries. For instance, introduce improved cereal crop varieties, increase CCA and familiarizes agricultural credits through formal institutions on relaxed conditions and on lowinterest rates could reduce the CPD's vulnerability to climate shocks.

Originality/value - To the best of the authors' knowledge, this study is the first attempt to examine the short- and long-term impacts of CC on CPD in Bangladesh over 1988-2014. The authors used various econometrics techniques, including the ARDL approach, the Granger causality test based on the vector error correction model framework and the variance decomposition method.

Keywords Bangladesh, ARDL bounds testing, Cereal production, Climatic factors

Paper type Research paper

\section{Introduction}

Agriculture is still the largest source of livelihood in developing nations and the backbone of the South Asian economy. South Asia feeds the world's $20 \%$ population with merely $5 \%$ of the world's agricultural land. The importance of agriculture in South Asia can be estimated from the fact that $70 \%$ of its population is living in villages, and agriculture is the main income source for this huge portion (Almazroui et al., 2020; Bandara and Cai, 2014). This region is ranked among the poorest of the world, and a significant proportion of people is suffering from insufficient food (Chandio et al., 2021a). Agriculture production has been increased through several measures, including technological improvements, increased use of fertilizers, improved seeds and utilization of additional cultivation areas. These drivers have improved productivity but caused severe climatic changes, and these changes have a significant connection with the environment and agriculture production (Chandio et al., 2021b). Thus, exploring the impact of climatic and non-climatic factors has substantial importance for developing nations like Bangladesh.

Presently, climate change (CC) is an important issue in both developing and developed countries, and the agriculture sector is more adversely affected by CC in particular (Mackay, 2008). According to the Intergovernmental Panel on Climate Change (IPCC) (2014) reported that climatic factors, including high temperatures, rainfall, $\mathrm{CO}_{2} \mathrm{e}$ and cyclones, are severely affecting all aspects of agriculture, such as production, distribution and food prices. Similarly, the changing frequency and severity of drought and flooding may have an adverse effect on food security (Beggs and Walczyk, 2008; Praveen and Sharma, 2019; Wang et al., 2018; Ziska et al., 2016). Thus, CC is very influential in the agriculture sector, and it is the main threat to all economic sectors around the world (Chandio et al., 2020a; De Vrese et al., 2018; Wang et al., 2018; Yawson et al., 2017).

Bangladesh is extremely vulnerable to $\mathrm{CC}$, mainly due to low and very flat land, the substance being flooded on the shoreline, and its susceptibility to rising sea levels (Alam et al., 2016; Alam, 2015; Islam and Nurseybray, 2017; Sarker et al., 2014). Challenges and natural disasters in the countries of the region, particularly on the coast of Bengal, have resulted from CC. The increased sea level and coastal erosion might lead to a loss of $17 \%$ of the country's production and 30\% of food production by 2052 (MoA, 2017). The agriculture sector remains the backbone of the Bangladeshi economy since it contributes $19.6 \%$ to the gross domestic product (GDP) (MoA, 2017). However, agricultural growth is hindered by several factors such as political, economic and environmental, respectively. Figure 1 
presents the trend of per capita $\mathrm{CO}_{2} \mathrm{e}$ in Bangladesh from 1985 to 2016. Bangladesh is a low $\mathrm{CO}_{2}$ emitter country in South Asia compared to India and Pakistan. However, the tendencies of $\mathrm{CO}_{2} \mathrm{e}$ is increasing from 0.11 metric tons per capita in 1985 to 0.53 metric tons per capita in 2016 in Bangladesh (Ahmed, 2018; WDI, 2017).

Figure 2 shows the trend of CPD and cultivated area from 1985 to 2016. It indicates that CPD has substantially increased from 24.1 metric tons to 54.3 metric tons during the period from 1985 to 2016. Likewise, the area under cereal cultivation in Bangladesh has fluctuated over the period (WDI, 2017).

Agricultural production is severely affected by the impacts of climatic factors and creating a high risk of food insecurity for the large population of Bangladesh (Islam and Nurseybray, 2017). Crop farming in different regions of Bangladesh is very vulnerable to CC. In Bangladesh, CC is a significant determinant of crop yield inconsistency (Sikder and Xiaoying, 2014). CC significantly affects food and non-food crop yields and efficiency and leads to important changes in agricultural output (Arshad et al., 2018; IPCC, 2014). Furthermore, the farming sector is adversely affected by extreme events of $\mathrm{CC}$, soil salinity in coastal areas and the occurrence of pests and diseases (Rosenzweig et al., 2001). Changes in rainfall patterns and increases in temperatures are already evident in Bangladesh (Shahid, 2011; Shahid et al., 2012). In Bangladesh, the daily average temperature has risen by $0.103^{\circ} \mathrm{C}$ since over the past four decades (Shahid et al., 2012). The report from the IPCC (2007) suggested that temperature will continue to increase by $1^{\circ} \mathrm{C}$ by $2030,1.4^{\circ} \mathrm{C}$ by 2050 and $2.4^{\circ} \mathrm{C}$ by 2100 due to global warming in Bangladesh.

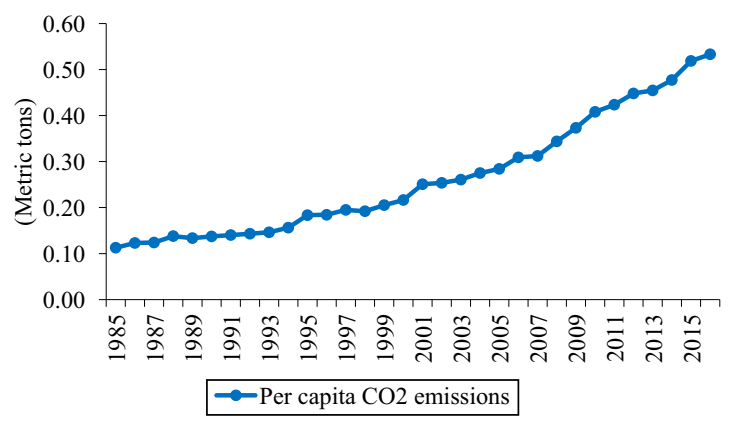

Source: World development indicators (2017)

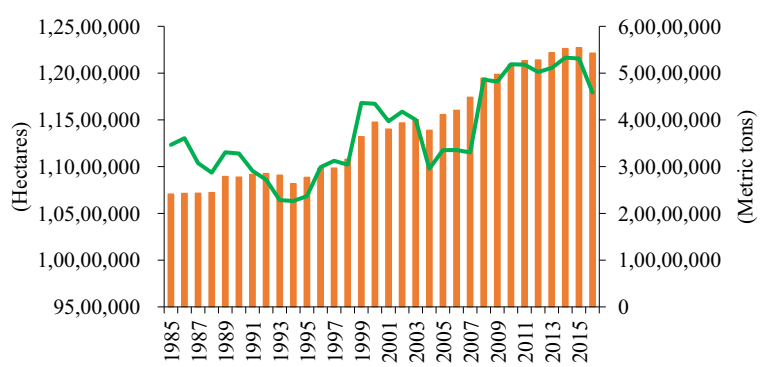

Cereal production $\quad$ Land under cereal production

Source: World development indicators (2017)
Impacts of climate change on cereal production
Figure 1. Per capita $\mathrm{CO}_{2}$ emissions in Bangladesh
Figure 2. Cereal production and land area in Bangladesh 
IJCCSM

14,2

Among cereal crops, rice accounts for $95.48 \%$ of the country's total grain production, and it is the most affected crop by flood and drought (Hussain, 2011). Land degradation due to sealevel rise negatively affects rice production in many coastal districts of Bangladesh (Dasgupta et al., 2014). The consequences of CC are expected to reduce cumulative agricultural land productivity by $-5 \%$ to $-13 \%$ in Bangladesh by 2030 for rice, wheat and CPD (Bandara and Cai, 2014).

Considering the important connection between climate and agricultural productivity, several global studies have examined the connection between $\mathrm{CC}$ and crop yields through various methods. Previous investigation on CC and agriculture has been focused on in developed and developing countries (Adams et al., 1995; Adams et al., 1988; Follett, 1993; Reilly et al., 2001). However, in recent years, several studies have addressed the CC impacts on agricultural production in developing countries (Deressa and Hassan, 2009; Haim et al., 2008; Mendelsohn et al., 1999; Molua, 2009; Ochieng et al., 2016; Voortman et al., 1999; Wang et al., 2009). All these studies have shown that agriculture is highly vulnerable to CC.

In a more comprehensive study, Chandio et al. (2020a) explored the CC-agricultural output nexus applying the auto-regressive distributive lag (ARDL) approach. Findings revealed that climatic factors such as temperature and rainfall have detrimental effects on agricultural output in the long-run, whereas $\mathrm{CO}_{2} \mathrm{e}$ significantly improves agricultural output both in the short- and long-run. More recently, Pickson et al. (2020) assessed the impacts of climatic and non-climatic factors on cereals production in China using the ADRL approach, outcomes exhibited that average temperature, temperature variability and $\mathrm{CO}_{2} \mathrm{e}$ have adverse effects on CPD both in long- and short-run, whereas, precipitation, cereals area under cultivation, energy used and rural labor force (RLF) improves the cereals production in both cases.

Ahsan et al. (2020) examined the $\mathrm{CO}_{2} \mathrm{e}-\mathrm{CPD}$ nexus in Pakistan, and findings showed that $\mathrm{CO}_{2} \mathrm{e}$ has positive effects on $\mathrm{CPD}$ in the long-run, while in the short-run, $\mathrm{CO}_{2} \mathrm{e}$ has negative effects on it. Further results revealed two-way causality between $\mathrm{CO}_{2} \mathrm{e}$ and CPD. This result supports the findings of Sarkodie and Owusu (2017) and Asumadusarkodie and Owusu (2017), who also found two-way causality between cereal crop production and $\mathrm{CO}_{2} \mathrm{e}$ in Ghana. Furthermore, Attiaoui and Boufateh (2019) evaluated the effects of climatic factors on CPD in Tunisia. Findings revealed that rainfall has significantly positive effects and increases CPD, whereas temperature significantly hampers CPD. Sossou et al. (2020) estimated the impacts of CC on cereal yields in Burkina Faso over the period of 1991-2016. Results showed that temperature adversely affected yield and CPD, while precipitation has a positive effect.

Recent studies also explored that $\mathrm{CC}$ has an adverse effect on the atmosphere in Bangladesh. The different climatic variables such as heat, rainfall, moisture and sunshine have significant impacts on the major production of food crops (Chowdhury and Khan, 2015; Hossain et al., 2019; Huq et al., 2015; Masum and Hasan, 2013; Sarker et al., 2012). Ruttan (2002) reported that precipitation and sunlight could potentially alter agricultural productivity, but the gross effect was large in Bangladesh. Chowdhury and Khan (2015) examined the effects of CC on the yield of rice in Bangladesh from 1972-2014 by applying the ordinary least-squares (OLS) method. The results showed that maximum temperature has negative impacts on the yield of rice, whereas precipitation and humidity have positive impacts on the yield of rice in Bangladesh. Sarker et al. (2012) assessed the effects of CC variables on the yield of three major rice crops in Bangladesh from 1972-2009 by using the OLS and median (quantile) regression approaches. Findings revealed that maximum temperature has statistically positive impacts on Aus and Aman rice and adversely affected Boro rice, whereas Aman rice is adversely affected by minimum and positively improves 
Boro rice. Additionally, results showed that precipitation statistically improves Aus and Aman rice in Bangladesh. Whereas another group of studies (Ahsan et al., 2010; Chowdhury and Khan, 2015; Iqbal and Siddique, 2015; Islam and Nurseybray, 2017; Rehman et al., 2019; Sikder and Xiaoying, 2014) confirmed that CC had a significant effect on agriculture production in Bangladesh.

Based on the above background, the prime purpose of this study is to examine the effects of $\mathrm{CC}$ on $\mathrm{CPD}$ in the case of Bangladesh. This research work contributes to the existing literature in several ways. First, there is limited literature that examines the short- and longterm impacts of CC on CPD by applying the ARDL method and the vector error correction model (VECM) Granger causality framework in the context of Bangladesh. The present study fills this gap by examining the short- and long-term impacts of climatic factors (via temperature, $\mathrm{CO}_{2} \mathrm{e}$ and rainfall) on $\mathrm{CPD}$, with controlling for several non-climatic variables, such as cereal cropped area (CCA), financial development (FD), energy consumption (EC) and labor force, respectively, by using the ARDL model. Second, the VECM Grangercausality framework is used to discover the short-run causal connections amid the selected variables, which makes this investigation unique compared to earlier studies. Third, the variance decomposition method (VDM) is estimated to verify the certainty of the causal linkages between the chosen variables. The dynamic associations between the study variables are displayed in Figure 3.

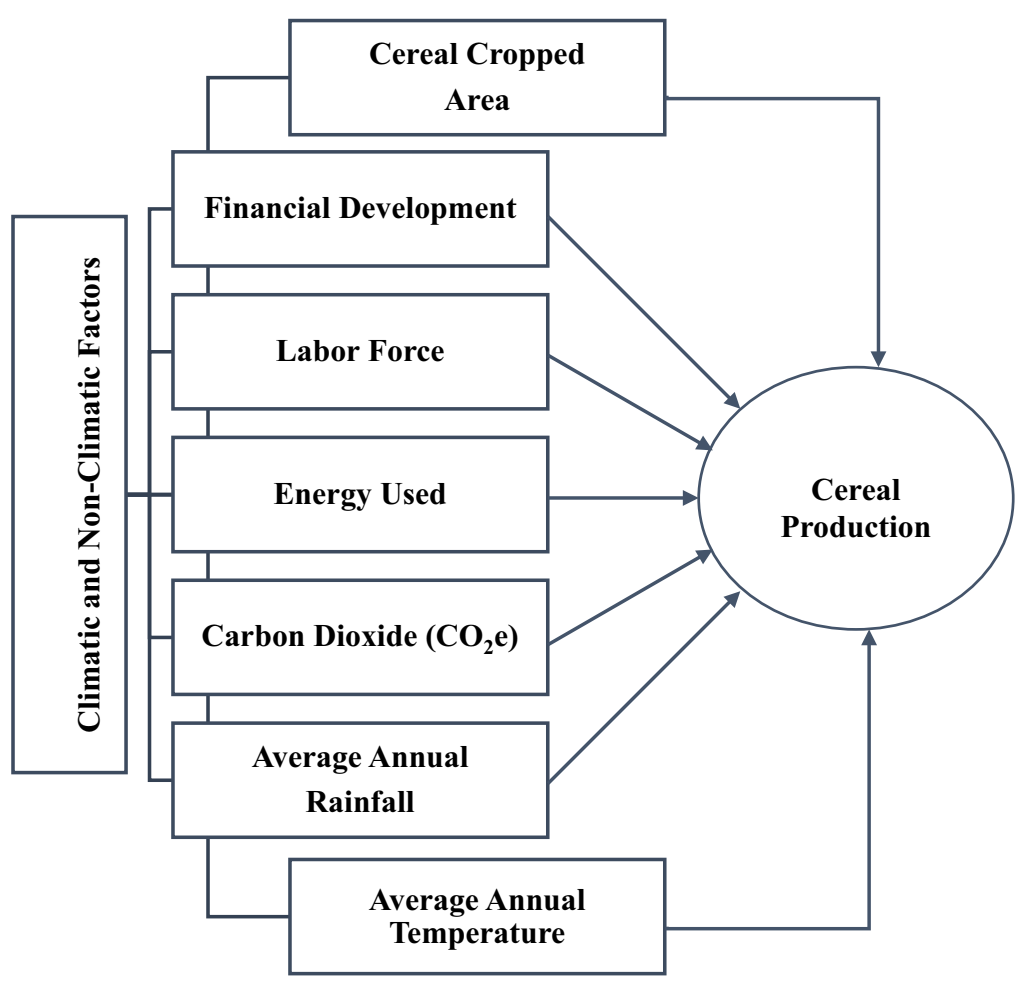

Impacts of climate change on cereal production
Figure 3.

Dynamic interactions between the study variables. 
IJCCSM

14,2

\section{Methodology}

\subsection{Data and model specification}

The present study uses annual data from the period 1988-2014. For estimation purposes, this study selected climatic and non-climatic variables such as average annual temperature (AAT), average annual rainfall (AAR), carbon dioxide $\left(\mathrm{CO}_{2} \mathrm{e}\right), \mathrm{CCA}$, domestic credit to the private sector as a proxy of FD, energy use per capita, rural population as a proxy of the RLF and CPD. The description of the variables is reported in the Appendix (Table A1).

The summary statistics and correlation results are reported in the Appendix (Table A2. The average value and corresponding long-term mean for CPD is 17.42 (0.26); temperature, 3.23 (0.01); rainfall, 5.15 (0.42); $\mathrm{CO}_{2} \mathrm{e}, 10.35$ (0.53); $\mathrm{CCA}, 16.24$ (0.04); FD, 3.15 (0.37); energy used, 5.05 (0.21); RLF, 4.32 (0.05). Table A2 also displays the correlation results, indicating that rainfall, $\mathrm{CO}_{2} \mathrm{e}, \mathrm{CCA}, \mathrm{FD}$ and energy used positively and strongly correlate with $\mathrm{CPD}$, while temperature positively but weakly correlated with CPD. In addition, the labor force negatively correlated with CPD. The trend of climatic and non-climatic variables is shown in Figure S1.

In the past, a few studies have been carried out to investigate the potential impact of $\mathrm{CC}$ on crop production in Bangladesh (Hossain et al., 2019; Sarker et al., 2012, 2014). The present study is an interesting addition to available literature to assess the short- and long-term impacts of climatic variables, namely, temperature, precipitation and $\mathrm{CO}_{2}$ emissions, on $\mathrm{CPD}$. To the best of our knowledge, the ARDL approach is used for the first time to investigate $\mathrm{CC}$ factors (i.e. emissions $\mathrm{CO}_{2}$, temperature and rainfall) affecting $\mathrm{CPD}$ using the time series data set from 1988 to 2014 for Bangladesh. To check the direction and validity of the causal relationship between the variables, this study also used the VECM-based Granger causality test. Therefore, this study is a valuable work from the Bangladeshi perspective and provides interesting findings for policymakers.

The general form of $\mathrm{CPD}$ function can be expressed as follows:

$$
C P D_{t}=f\left(A A T_{t}, A A R_{t}, C O_{2 t}, C C A_{t}, F D_{t}, E C_{t}, R L F_{t}\right)
$$

where $\mathrm{CPD}$ represents cereal production, AAT refers to average annual temperature, AAR is average annual rainfall, $\mathrm{CO}_{2}$ indicates the carbon dioxide emissions, $\mathrm{CCA}$ is cereal cropped area, FD stands for financial development, EC shows the energy consumption, RLF is rural labor force and $t$ denotes the period (years). All the study variables are taken in their natural logarithm form, and the linear model is constructed as follows:

$$
\begin{aligned}
\log C P D_{t}= & \mathrm{\Upsilon}_{0}+\mathrm{\Upsilon}_{1} \log A A T_{t}+\mathrm{\Upsilon}_{2} \log A A R_{t}+\mathrm{\Upsilon}_{3} \log C O_{2 t}+\mathrm{\Upsilon}_{4} \log C C A_{t}+\mathrm{\Upsilon}_{5} \log F D_{t} \\
& +\mathrm{\Upsilon}_{6} \log E C_{t}+\mathrm{\Upsilon}_{7} \log R L F_{t}+\varepsilon_{t}
\end{aligned}
$$

where $\Upsilon_{1}, \Upsilon_{2}, \Upsilon_{3}, \Upsilon_{4}, \Upsilon_{5}, \Upsilon_{6}, \Upsilon_{7}$ represent the coefficients to be estimated, $\Upsilon_{0}$ is the intercept, and $\varepsilon_{t}$ refers to the error term.

The reasons for using $\log \mathrm{CPD}, \log \mathrm{AAT}, \log \mathrm{AAR}, \log \mathrm{CO}_{2} \mathrm{e}, \log \mathrm{CCA}, \log \mathrm{FD}, \log \mathrm{EC}$ and $\operatorname{logRLF}$ in equation (2) are specified as follows. Numerous scholars have analyzed the interconnections between climatic factors and CPD in different regions of the world (Ahsan et al, 2020; Chowdhury and Khan, 2015; Guntukula, 2020; Pickson et al, 2020; Warsame et al, 2021). Based on the prior results, AAT and $\mathrm{CO}_{2}$ e negatively affects $\mathrm{CPD}$ (Ahmad et al., 2020; Attiaoui and Boufateh, 2019; Boansi, 2017; Pickson et al., 2020), while AAR is projected texert a positive impact on CPD (Anh et al., 2020; Chandio et al., 2020b; Warsame et al., 2021). Several authors (Shahbaz et al., 2013; Anh et al, 2020; Zakaria et al., 2019) suggested that domestic credit to the private sector is a suitable proxy for FD, and it plays a significant role to boost agricultural production. In the current study, we have introduced other non-climatic as important factors of CPD, including CCA, EC and RLF. Several previous scholars (Chandio 
et al., 2019; Inumula et al., 2020; Warsame et al., 2021) also incorporated these non-climatic factors into their model.

\subsection{Auto-regressive distributive lag modeling approach}

The present study uses the ARDL approach with the help of unrestricted VECM to discover the long-term association between temperature, rainfall, CO2e, CCA, FD, energy used, labor force and CPD in Bangladesh. This approach is primarily developed by Pesaran and Shin (1998) and Pesaran et al. (2001). As compared to other co-integrations, the ARDL method has a couple of advantages, such as it can be used irrespective of whether the series is purely cointegrated at the $I(0), I(1)$, or mutually and estimated small sample properties (Pesaran et al., 2001; Shahbaz et al., 2013). Following the previous studies (Ahmed et al., 2021; Ali et al., 2019; Anh et al., 2020; Eregha et al., 2014; Omoregie et al., 2018; Raifu and Aminu, 2019; Zhai et al., 2017), the ARDL model is constructed as follows:

$$
\begin{aligned}
\Delta \log C P D_{t}= & \psi_{0}+\sum_{i=1}^{p} \psi_{1 i} \Delta \log C P D_{t-i}+\sum_{i=1}^{p} \psi_{2 i} \Delta \log A A T_{t-i}+\sum_{i=1}^{p} \psi_{3 i} \Delta \log A A R_{t-i} \\
& +\sum_{i=1}^{p} \psi_{4 i} \Delta \log C O_{2 t-i}+\sum_{i=1}^{p} \psi_{5 i} \Delta \log C C A_{t-i}+\sum_{i=1}^{p} \psi_{6 i} \Delta \log F D_{t-i} \\
& +\sum_{i=1}^{p} \psi_{7 i} \Delta \log E C_{t-i}+\sum_{i=1}^{p} \psi_{8 i} \Delta \log R L F_{t-i}+\lambda_{1} \log C P D_{t-1}+\lambda_{2} \log A A T_{t-1} \\
& +\lambda_{3} \log A A R_{t-1}+\lambda_{4} \log C O_{2 t-1}+\lambda_{5} \log C C A_{t-1}+\lambda_{6} \log F D_{t-1}+\lambda_{7} \log E C_{t-1} \\
& +\lambda_{8} \log R L F_{t-1}+\varepsilon_{t}
\end{aligned}
$$

where $\Psi_{0}$ refers to the constant, $\varepsilon_{t}$ denotes the error term, the first part of the equation presents the error correction dynamics and the second part of the equation indicates the long-term association. We used the ARDL-bound $F$-stat to examine the long-term association between temperature, rainfall, $\mathrm{CO}_{2}$ emissions, $\mathrm{CCA}, \mathrm{FD}$, energy used, labor force and $\mathrm{CPD}$. The null hypothesis of no long-term co-integration between the variables is rejected if the calculated $F$-stat exceeds the value of the critical upper bound. If the computed $F$-stat is below the lower critical bound, then the null hypothesis of no long-term co-integration is accepted. In addition, if the $F$-stat falls between both upper and lower critical bounds, then the obtained outcomes are said to be inconclusive. The short-run dynamics and the error correction term can be derived by using the following ARDL model:

$$
\begin{aligned}
\Delta \log C P D_{t}= & \beta_{0}+\sum_{i=1}^{p} \beta_{1 i} \Delta \log C P D_{t-i}+\sum_{i=1}^{p} \beta_{2 i} \Delta \log A A T_{t-i}+\sum_{i=1}^{p} \beta_{3 i} \Delta \log A A R_{t-i} \\
& +\sum_{i=1}^{p} \beta_{4 i} \Delta \log C O_{2 t-i}+\sum_{i=1}^{p} \beta_{5 i} \Delta \log C C A_{t-i}+\sum_{i=1}^{p} \beta_{6 i} \Delta \log F D_{t-i} \\
& +\sum_{i=1}^{p} \beta_{7 i} \Delta \log E C_{t-i}+\sum_{i=1}^{p} \beta_{8 i} \Delta \log R L F_{t-i}+\eta E C M_{t-1}+\varepsilon_{t}
\end{aligned}
$$

Impacts of climate change on cereal production 
IJCCSM

14,2

\section{2}

\section{Empirical results and discussions}

\subsection{Unit root tests results}

For checking the stationary of the study variables, we used the augmented Dickey-Fuller $(\mathrm{ADF})$ and Phillips and Perron $(\mathrm{PP})$ unit root tests, and obtained results are reported in Table 1. First, both unit root tests are applied on their level of the study variables and then on the first difference. The results of both the $\mathrm{ADF}$ and $\mathrm{PP}$ tests in Table 3 demonstrated that all variables are stationary at the first difference $I(1)$. Thus, these tests suggest that to use the ARDL model.

\subsection{Cointegration testing results}

For exploring the long-term connections between the variables, we applied the ARDL bound testing method. The results are presented in Table 2. The obtained results of the ARDL bound testing

Table 1.

\begin{tabular}{|c|c|c|c|c|}
\hline \multirow[t]{2}{*}{ Variables } & \multicolumn{2}{|c|}{ ADF test statistic } & \multicolumn{2}{|c|}{ PP test statistics } \\
\hline & Level & First difference & Level & First difference \\
\hline $\log \mathrm{CPD}$ & -3.9601 & $-5.3380 * * * *$ & -3.2380 & -5.0593 *** \\
\hline logAAT & -0.3352 & $-4.9812 * * *$ & -0.8022 & $-7.7925 * * *$ \\
\hline $\log A A R$ & -0.1301 & $-8.1540^{* * * *}$ & -0.5467 & $-5.4618^{* * * *}$ \\
\hline $\log \mathrm{CO}_{2} \mathrm{e}$ & -3.1605 & $-4.5748^{* * * *}$ & -3.7415 & $-6.3527^{* * * *}$ \\
\hline $\log C \mathrm{~A}$ & -0.9805 & $-4.8331^{* * * *}$ & -2.3307 & $-5.2203^{* * * *}$ \\
\hline $\log F D$ & -4.0699 & $-5.1468^{* * * *}$ & -3.6821 & $-5.5223^{* * * *}$ \\
\hline $\operatorname{logEC}$ & -1.7750 & $-6.2606^{* * * *}$ & -1.6161 & $-6.5590^{* * * *}$ \\
\hline logRLF & -1.5927 & $-5.5899 * * *$ & -0.5780 & $-4.5131^{* * * *}$ \\
\hline
\end{tabular}

Unit root test results Note: $* * *$ shows the significance at $1 \%$

\begin{tabular}{|c|c|c|c|}
\hline $\begin{array}{l}\text { Dependent } \\
\text { variable }\end{array}$ & Estimated models & Lag order & $F$-statistics \\
\hline $\log \mathrm{CPD}$ & $\begin{array}{l}\mathrm{F}_{\log \mathrm{CPD}}\left(\log \mathrm{CPD} / \log \mathrm{AAT}, \log \mathrm{AAR}, \log \mathrm{CO}_{2}, \log \mathrm{CCA}, \log \mathrm{FD},\right. \\
\log \mathrm{EC}, \log \mathrm{RLF})\end{array}$ & $\begin{array}{l}(1,2,2,2,2 \\
\quad 2,2,1)\end{array}$ & 5.3450 **** \\
\hline $\log \mathrm{AAT}$ & $\begin{array}{l}\mathrm{F}_{\log A \mathrm{~T}}\left(\log \mathrm{AAT} / \log \mathrm{CPD}, \log \mathrm{AAR}, \log \mathrm{CO}_{2}, \log \mathrm{CCA}, \log \mathrm{FD},\right. \\
\log \mathrm{EC}, \log \mathrm{RF})\end{array}$ & $\begin{array}{l}(1,2,2,2,0 \\
\quad 1,2,2)\end{array}$ & 1.6286 \\
\hline $\log A A R$ & $\begin{array}{l}\text { Flog } \\
\log \mathrm{AC}, \log (\log \mathrm{AAR})\end{array}$ & $\begin{array}{l}(1,2,1,2,2 \\
0,2,1)\end{array}$ & $6.9821 * * *$ \\
\hline $\log \mathrm{CO}_{2} \mathrm{e}$ & $\begin{array}{l}\mathrm{Flog}_{\mathrm{CO} 2}\left(\log \mathrm{CO}_{2} / \log \mathrm{AAR}, \log \mathrm{AAT}, \log \mathrm{CPD}, \log \mathrm{CCA}, \log \mathrm{FD}\right. \\
\log \mathrm{EC}, \log \mathrm{RF})\end{array}$ & $\begin{array}{l}(1,1,2,2,2 \\
2,2,2)\end{array}$ & $4.5841^{* *}$ \\
\hline $\log \mathrm{CCA}$ & $\begin{array}{l}\text { Flog } \operatorname{locA}_{(\log C A} / \log \mathrm{CO}_{2}, \log \mathrm{AAR}, \log \mathrm{AAT}, \log \mathrm{CPD}, \log \mathrm{FD}, \\
\log \mathrm{EC}, \log \mathrm{RF})\end{array}$ & $\begin{array}{l}(1,2,2,2,2 \\
2,1,2)\end{array}$ & $6.9919 * * *$ \\
\hline $\log F D$ & $\begin{array}{l}\text { Flog } \\
\log \mathrm{EC}, \log \mathrm{l} \mathrm{LLF})\end{array}$ & $\begin{array}{l}(1,2,2,2,2 \\
\quad 2,1,2)\end{array}$ & $6.9169 * * *$ \\
\hline $\log \mathrm{EC}$ & $\begin{array}{l}\mathrm{Flog}_{\mathrm{EC}}\left(\log \mathrm{EC} / \log \mathrm{FD}, \log \mathrm{CCA}, \log \mathrm{CO}_{2}, \log \mathrm{AAR}, \log \mathrm{AAT}, \log \mathrm{CPD},\right. \\
\log \mathrm{RF})\end{array}$ & $\begin{array}{l}(1,1,2,2,2 \\
2,2,2)\end{array}$ & $8.2958 * * *$ \\
\hline $\log \mathrm{RLF}$ & $\begin{array}{l}\text { Flog RLF }\left(\log R L F / \operatorname{logEC}, \log \mathrm{FD}, \log \mathrm{CCA}, \log \mathrm{CO}_{2}, \log \mathrm{AAR},\right. \\
\log \mathrm{AAT}, \log \mathrm{CPD})\end{array}$ & $\begin{array}{l}(1,1,2,2,2 \\
\quad 2,1,1)\end{array}$ & $22.4935^{* * * *}$ \\
\hline Significance & Lower bound & Upper bound & \\
\hline $1 \%$ & 3.31 & 3.45 & \\
\hline $5 \%$ & 2.98 & 3.83 & \\
\hline $10 \%$ & 2.38 & 4.63 & \\
\hline
\end{tabular}

Table 2.

ARDL-Bounds testing results 


\begin{tabular}{|c|c|c|c|c|c|}
\hline Variables & Coefficient & Standard error & $t$-statistic & Prob. & $\begin{array}{l}\text { Impacts of } \\
\text { climate change }\end{array}$ \\
\hline \multicolumn{5}{|c|}{ Panel A: Estimated long-term coefficients } & on cereal \\
\hline $\log \mathrm{AAT}$ & 0.0735 & 0.3640 & 0.2021 & 0.8497 & production \\
\hline $\operatorname{logAAR}$ & $0.1083^{* * *}$ & 0.0234 & 4.6115 & 0.0099 & productio \\
\hline $\log _{2}$ & $-1.5840^{* *}$ & 0.4423 & -3.5811 & 0.0231 & \\
\hline $\log C \mathrm{~A}$ & $1.5341^{* * *}$ & 0.2419 & 6.3412 & 0.0032 & \\
\hline $\operatorname{logFD}$ & $0.7984 * *$ & 0.2154 & 3.7064 & 0.0207 & 133 \\
\hline $\log E C$ & 0.0680 & 0.7276 & 0.0935 & 0.9300 & \\
\hline $\operatorname{logRLF}$ & 1.2103 & 2.1586 & 0.5607 & 0.6049 & \\
\hline $\mathrm{C}$ & -2.6577 & 6.6415 & -0.4001 & 0.7095 & \\
\hline @TREND & $0.0966^{* * *}$ & 0.0184 & 5.2508 & 0.0063 & \\
\hline \multicolumn{6}{|c|}{ Panel B: Estimated short-term coefficients } \\
\hline $\operatorname{Dlog} \mathrm{CPD}(-1)$ & $0.3152^{*}$ & 0.1360 & 2.3182 & 0.0813 & \\
\hline DlogAAT & $-0.3263^{*}$ & 0.1295 & -2.5189 & 0.0654 & \\
\hline $\operatorname{DlogAAT}(-1)$ & $0.5121 * *$ & 0.1434 & 3.5697 & 0.0234 & \\
\hline DlogAAT(-2) & -0.1354 & 0.1646 & -0.8227 & 0.4569 & \\
\hline DlogAAR & $0.0538^{* * * *}$ & 0.0056 & 9.5649 & 0.0007 & \\
\hline $\operatorname{DlogAAR}(-1)$ & $-0.0154^{*}$ & 0.0062 & -2.4722 & 0.0688 & \\
\hline $\operatorname{Dlog} A A R(-2)$ & $0.0357 * * *$ & 0.0059 & 6.0200 & 0.0038 & \\
\hline $\mathrm{DlogCO}_{2}$ & $-0.4945^{* * * *}$ & 0.0784 & -6.3025 & 0.0032 & \\
\hline $\mathrm{DlogCO}_{2}(-1)$ & -0.0996 & 0.0572 & -1.7406 & 0.1567 & \\
\hline $\operatorname{DlogCO}_{2}(-2)$ & $-0.4903^{* * *}$ & 0.0657 & -7.4604 & 0.0017 & \\
\hline $\mathrm{D} \log \mathrm{CCA}$ & $1.5810^{* * * *}$ & 0.1021 & 15.4772 & 0.0001 & \\
\hline $\operatorname{DlogCCA}(-1)$ & $-0.6734 * *$ & 0.2571 & -2.6183 & 0.0589 & \\
\hline $\operatorname{DlogCCA}(-2)$ & 0.1428 & 0.0714 & 1.9976 & 0.1164 & \\
\hline DlogFD & $0.3701^{* * * *}$ & 0.0518 & 7.1416 & 0.0020 & \\
\hline $\operatorname{DlogFD}(-1)$ & 0.0772 & 0.0387 & 1.9942 & 0.1169 & \\
\hline $\operatorname{DlogFD}(-2)$ & 0.0993 & 0.0467 & 2.1233 & 0.1010 & \\
\hline$D \log E C$ & $0.3923 * *$ & 0.1479 & 2.6524 & 0.0568 & \\
\hline $\operatorname{Dlog} E C(-1)$ & $-0.6656^{* * *}$ & 0.1355 & -4.9109 & 0.0080 & \\
\hline $\operatorname{Dlog} E C(-2)$ & 0.3199 & 0.3037 & 1.0534 & 0.3515 & \\
\hline DlogRLF & -6.2855 & 3.1951 & -1.9672 & 0.1205 & \\
\hline $\operatorname{DlogRLF}(-1)$ & $7.1143^{* *}$ & 2.4185 & 2.9415 & 0.0423 & \\
\hline $\mathrm{C}$ & -1.8198 & 4.2621 & -0.4269 & 0.6914 & \\
\hline D@TREND & $0.0661^{* * * *}$ & 0.0046 & 14.1838 & 0.0001 & \\
\hline CointEq(-1) & $-0.6847^{* * *}$ & 0.1360 & -5.0344 & 0.0073 & \\
\hline \multicolumn{6}{|c|}{ Panel C: Diagnostic tests } \\
\hline Test statistics & Statistic value & Prob. & & & \\
\hline Serial correlation & 1.4507 & 0.2844 & & & \\
\hline Normality & 0.8971 & 0.6385 & & & \\
\hline $\mathrm{ARCH}$ & 3.5658 & 0.2397 & & & \\
\hline Ramsey & 0.9934 & 0.3924 & & & Table 3. \\
\hline \multicolumn{5}{|c|}{ Note: $* * *, * *$ and $*$ show the significance at 1,5 and $10 \%$, respectively } & short-term results \\
\hline
\end{tabular}

approach in Table 3 exhibited that the calculated $F$-statistics 5.3450, 6.9821, 4.5841, 6.9919, 6.9169, 8.2958 and 22.4935 are higher than the upper bound critical value at $1 \%$ and $5 \%$ significance level. Therefore, these results confirm that there is a strong long-term connection among temperature, rainfall, $\mathrm{CO}_{2}$ emissions, $\mathrm{CCA}$, FD, energy used, labor force and CPD. For robustness purposes, we also used the Johansen cointegration test. The results are shown in the Appendix (Table A3). The results of this test also confirm a long-term cointegration connection among temperature, rainfall, $\mathrm{CO}_{2}$ emissions, $\mathrm{CCA}$, FD, energy use, labor force and CPD. The trace statistic, as well as the MaxEigen statistic, show six cointegrating equations at $1 \%$ significance level. 
IJCCSM

14,2

\section{4}

\subsection{Long-and short-term results of the auto-regressive distributive lag model}

In the present study, we found a long-term cointegration connection among the study variables. Further, we derived the long- and short-term estimates of temperature, rainfall, $\mathrm{CO}_{2} \mathrm{e}, \mathrm{CCA}, \mathrm{FD}$, energy use, RLF and CPD using the ARDL method. The long- and shortterm results of the ARDL approach are reported in Table 3. The summary of the long-term relationship between the variables is demonstrated in Figure 4.

The findings reveal that climatic variables such as temperature and rainfall have a positive impact on CPD in the long-term. The long-term coefficients of both temperature and rainfall show that a $1 \%$ increase in temperature and rainfall will increase CPD by about $0.07 \%$ and $0.10 \%$. These results are similar to the results of Ammani et al. (2013), Chandio et al. (2020b), Guntukula (2020), Khan et al. (2019) and Sossou et al. (2020), who reported that average temperature and average rainfall have a significantly positive impact on CPD. On the other hand, Chandio et al. (2020c), Khan et al. (2019) and Warsame et al. (2021) found that temperature has a negative effect on CPD. Similarly, $\mathrm{CO}_{2} \mathrm{e}$ has a significantly negative impact on it. The long-term coefficient of $\mathrm{CO}_{2} \mathrm{e}$ indicates that a $1 \%$ increase in global CC will decrease CPD by $1.58 \%$. This result is similar to the findings of Chandio et al. (2020c), Eshete et al. (2020), Qureshi et al. (2016) and Sossou et al. (2020), who also found that $\mathrm{CO}_{2} \mathrm{e}$ has a negative effect on CPD.

Results further show that non-climatic variables such as CCA and FD have a significantly positive impact on CPD in the long-term. The long-term coefficients of CCA and FD show that a $1 \%$ increase in CCA and FD will enhance CPD by $1.53 \%$ and $0.79 \%$. These results are similar to the findings of Afrin et al. (2017), Agbodji and Johnson (2019), Ammani (2012), Shahbaz et al. (2013), Yazdi and Khanalizadeh (2014) and Zakaria et al. (2019), who found that FD has a significantly positive impact on agricultural production.

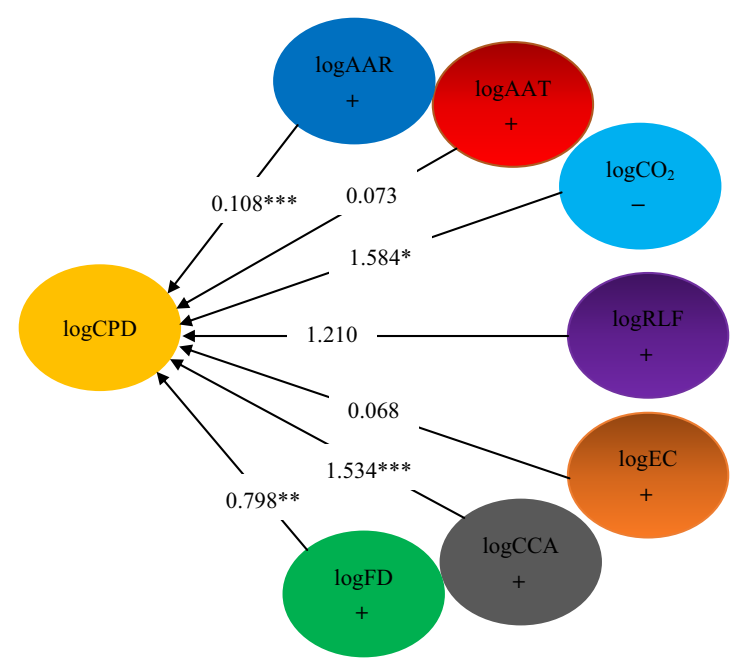

Figure 4.

Summary of the longterm relationship between the variables
Note: $* * *, * *$ and $*$ show the significance at $1 \%, 5 \%$, and $10 \%$ level, respectively. + sign indicates positive association and - sign indicates negative association among variables 
The short-term results of the ARDL method are also provided in Table 3. Climatic factors include temperature and $\mathrm{CO}_{2} \mathrm{e}$, have significantly negative effects on $\mathrm{CPD}$, while rainfall has a significantly positive effect on CPD in the short-run. The short-term coefficients of climatic factors such as temperature, $\mathrm{CO}_{2} \mathrm{e}$ and rainfall show that with a $1 \%$ increase in temperature, $\mathrm{CO}_{2} \mathrm{e}$ and rainfall will decrease $\mathrm{CPD}$ by $0.32 \%, 0.49 \%$ and increase by $0.05 \%$, respectively. In Bangladesh, $\mathrm{CC}$ has brought massive threats to the agricultural sector. Due to the geographical location, Bangladesh is a more vulnerable country to CC (Hasnisah et al., 2019). Alam and Islam (2018) reported that rising temperatures and flooding are more likely to decline the yield of major food crops in the southwestern coastal regions of Bangladesh. In addition, non-climatic factors such as CCA, FD and $\mathrm{EC}$ have a significantly positive effect on $\mathrm{CPD}$ in the short-run. The short-run coefficients of non-climatic factors indicate that with a $1 \%$ increase in CCA, FD and $\mathrm{EC}$ will improve CPD by $1.58 \%, 0.37 \%$ and $0.39 \%$, respectively.

To check the validity and consistency of the ARDL model, we used various diagnostics tests include serial correlation, normality, heteroscedasticity, functional form, the cumulative sum of recursive residuals (CUSUM) and cumulative sum of the square of recursive residuals (CUSUMSQ). Results of these tests are provided in Table 3, indicating that the findings of the ARDL model are valid and robust. Figures S2 and S3 show that the ARDL model is also stable.

\subsection{Results of vector error correction model approach}

The long-term connectivity is an indication of at least one side causality relationship among variables. To check the direction and validity of causal relationship, this study applied VECM-based Ganger causality. The results are reported in Table 4, and the first column describes the dependent variables. The values of the CPD model confirm that a significant two-way causal association is running from all variables to CPD except average temperature and rainfall (see Figure 5). The connection between CPD and temperature is unidirectional, showing that CPD is influenced by temperature. Therefore, the causal estimations are in the lines of ARDL results, indicating a significant association of independent variables with $\mathrm{CPD}$. The results of the remaining models indicate a unidirectional causality exists among $\mathrm{CPD}$, rainfall and $\mathrm{EC}$ to average temperature. Likewise, temperature, FD, EC and labor force link are significant with rainfall. The connection between EC and rainfall is two-way.

Using $\mathrm{CO}_{2}$ e as the dependent variable, the outcomes show a bidirectional link among $\mathrm{CPD}, \mathrm{FD}$, energy use and $\mathrm{CO}_{2} \mathrm{e}$. However, causality between labor and $\mathrm{CO}_{2} \mathrm{e}$ is unidirectional, and this link runs both ways between crop area and CPD, and a unidirectional link is significant for the labor force and crop area. Similarly, CPD, $\mathrm{CO}_{2} \mathrm{e}, \mathrm{EC}$ and labor force are connected with FD. On the same note, all variables have a causal link with EC. Finally, CPD and EC have a significant causal link with the labor force. Overall, results of both main and supplementary models indicate that variables share significant one-way and two-way causal relationships among each other. These outcomes are robust and support the main model findings that rainfall, temperature, energy use, FD and labor force have a significant connection with CPD of Bangladesh under VECM causal estimations.

\subsection{Results of variance decomposition approach}

This paper used the generalized forecast error VDM using the VAR system to test the strength and verify the certainty of the causal relationships between our main variables. The main feature of this method is that it is insensitive to the ordering of the variables, which is uniquely determined by the VAR system; further, it is able to estimate simultaneous shock effects. The estimated results are reported in Table 5. The 
IJCCSM

14,2

136

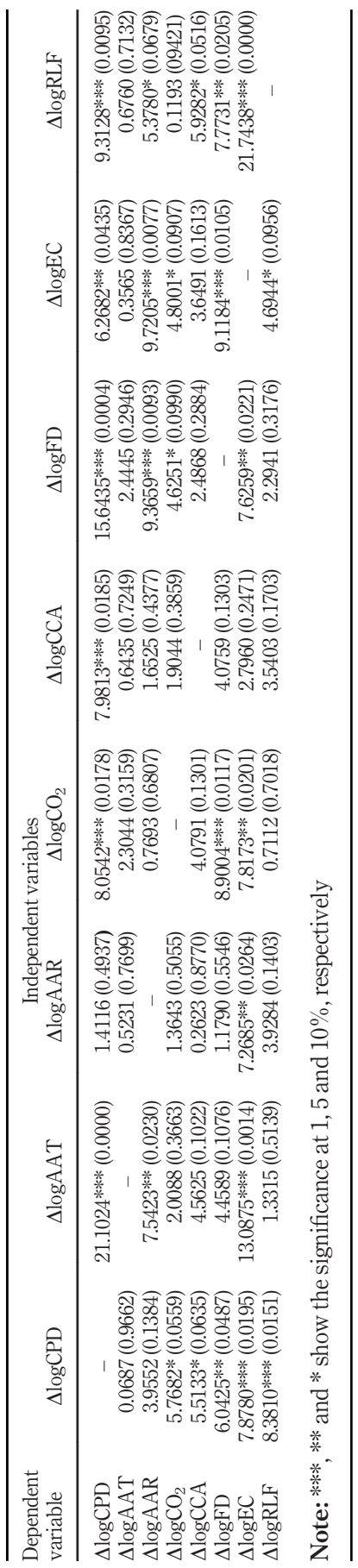

Table 4.

VECM-based ganger causality estimates 


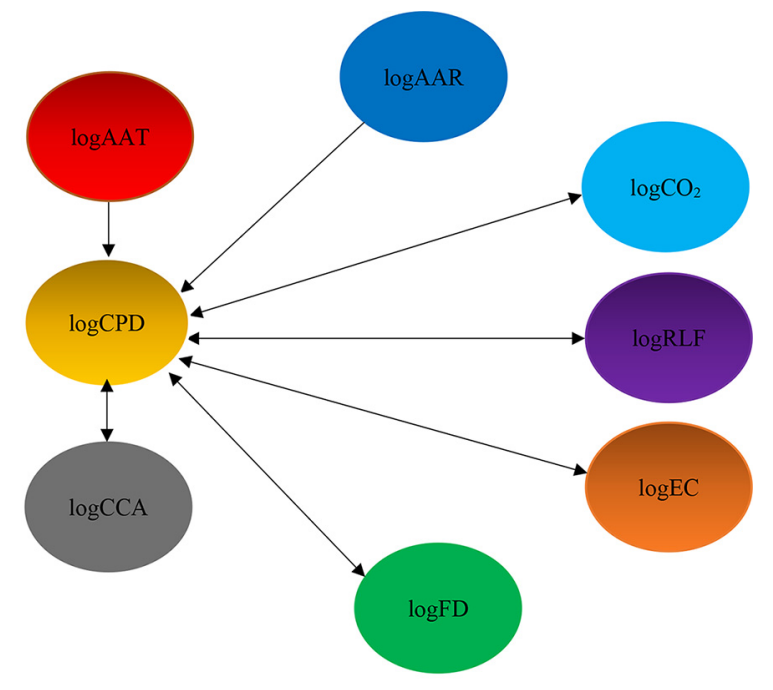

Unidirectional in the short-term Bidirectional in the short-term

Figure 5. Short-term causality analysis

\begin{tabular}{|c|c|c|c|c|c|c|c|c|c|c|}
\hline \multicolumn{11}{|c|}{ Variance decomposition of $\log \mathrm{CPD}$} \\
\hline 1 & 0.033 & 100.000 & 0.000 & 0.000 & 0.000 & 0.000 & 0.000 & 0.000 & 0.000 & \\
\hline 2 & 0.072 & 36.440 & 42.438 & 2.230 & 4.341 & 12.778 & 1.399 & 0.076 & 0.295 & \\
\hline 3 & 0.091 & 28.828 & 54.525 & 1.438 & 3.002 & 10.749 & 0.895 & 0.223 & 0.335 & \\
\hline 4 & 0.102 & 23.520 & 61.848 & 1.161 & 2.728 & 9.458 & 0.725 & 0.250 & 0.306 & \\
\hline 5 & 0.112 & 19.586 & 63.885 & 1.411 & 4.920 & 8.498 & 1.088 & 0.354 & 0.254 & \\
\hline 6 & 0.120 & 17.120 & 60.651 & 2.399 & 8.736 & 8.530 & 2.024 & 0.313 & 0.222 & \\
\hline 7 & 0.124 & 15.893 & 57.530 & 3.114 & 10.880 & 9.565 & 2.509 & 0.291 & 0.214 & Ta \\
\hline 8 & 0.129 & 14.854 & 54.904 & 3.842 & 12.082 & 10.943 & 2.853 & 0.308 & 0.209 & Variance \\
\hline 9 & 0.136 & 13.954 & 53.102 & 4.538 & 12.774 & 12.089 & 3.035 & 0.304 & 0.199 & decomposition \\
\hline 10 & 0.146 & 13.343 & 52.551 & 4.848 & 12.954 & 12.863 & 2.972 & 0.268 & 0.196 & results \\
\hline
\end{tabular}

decomposition of $\mathrm{CPD}$ shows that temperature is the most significant factor among others related to CPD. Environment and crop area is also notable and rainfall, as well as FD, comes after it. EC and labor are the least contributing factors; however, both variables indicate an increasing trend. Overall, the magnitude of contribution varies among variables, but all of them are associated with CPD.

\section{Conclusions, recommendations and limitations}

Bangladesh has a vast population with inadequate land area, while the annual growth rate of the population is $1.05 \%(\mathrm{WB}, 2019)$. Every year, with increasing industrialization, urbanization and population, agricultural land decreases by around 1\% (Alauddin and Biswas, 2014). In addition to these massive challenges, $\mathrm{CC}$ has also brought additional 
IJCCSM 14,2

hazards to the farming sector of Bangladesh. Therefore, this study assessed the impacts of climatic and non-climatic factors on CPD in Bangladesh over the period of 1988-2014 by using the ARDL model.

The empirical evidence exhibits a stable long-term connection among all considered variables. The long-term estimates of the ARDL model showed that climatic factors, including temperature and rainfall, have positive impacts on $\mathrm{CPD}$, while $\mathrm{CO}_{2}$ emissions have significantly negative impacts on it. Results further indicated that non-climatic factors like CCA, FD, EC and labor force also have positive impacts on CPD. The short-term estimates of the ARDL model based on ECM indicated that climatic factors such as temperature and $\mathrm{CO}_{2}$ emissions have significantly negative impacts on CPD, whereas rainfall has significant positive impacts on it. In addition, non-climatic factors like CCA, FD and $\mathrm{EC}$ have significantly positive impacts on CPD.

Furthermore, the Granger causality approach under VECM is used to check the direction of the relationship among all study variables. The results of the main model indicated that a significant two-way causal association is running from all variables to CPD except temperature and rainfall. The connection between CPD and temperature is unidirectional, showing that the production of cereal is influenced by temperature. All other variables also have a valid and significant causal link among each other.

This study found that temperature negatively impacted CPD in the long-term. Therefore, the long-term policies should focus on short-term preparedness and planning to counter the temperature impacts in the long-term. In this regard, the planning on the frequency of irrigation, type of fertilizers to be used and selection of breed of the seed may help counter the long-term negative impacts of the temperature. Moreover, the negative impact of $\mathrm{CO}_{2} \mathrm{e}$ in the long- and short-term implies that carbon concentrations are higher than the desired levels in the study area. Therefore, more plantation is required to reduce the carbon impacts in the short-and long-term.

There is no research without limitations, and therefore, there is always room for improvement. This research has taken two non-climate factors, including FD and EC, which were argued to be the most critical non-climate factors of CPD. However, there could be several other non-climate factors that might potentially impact CPD. The present research has not included those factors for underlying reasons. First, the inclusion of more variables in the model consumes the degree of freedom to estimate the parameters and thus could lead to poor estimates. Second, the inclusion of more control variables could shift the focus of this research away from the core climate factors of CPD. Therefore, future studies should solve these problems in the following ways. First, long time series data or, alternatively, panel data should be considered to solve the problem of the degree of freedom loss. Second, the control variables should be used in alternative models to provide inter-modeling comparisons of the impacts of those non-climate factors on CPD. Besides, future studies should assess the effects of $\mathrm{CC}$ factors (maximum and minimum temperatures, and precipitation) on major food and non-food crops yield by using time series data since this study inspected the impact of $\mathrm{CC}$ factors (emissions $\mathrm{CO}_{2}$, average temperature and average rainfall) on CPD in Bangladesh by using the ARDL approach.

\section{References}

Adams, R.M., Fleming, R.A., Chang, C., Mccarl, B.A. and Rosenzweig, C. (1995), "A reassessment of the economic effects of global climate change on US agriculture", Climatic Change, Vol. 30 No. 2, pp. 147-167.

Adams, R.M., Mccarl, B.A., Dudek, D.J. and Glyer, J.D. (1988), "Implications of global climate change for Western agriculture", Western Journal of Agricultural Economics, Vol. 13 No. 2, p. 348. 
Afrin, S., Haider, M.Z. and Islam, M.S. (2017), "Impact of financial inclusion on technical efficiency of paddy farmers in Bangladesh", Agricultural Finance Review, Vol. 77 No. 4, pp. 484-505, doi: 10.1108/AFR-06-2016-0058.

Agbodji, A.E. and Johnson, A.A. (2019), "Agricultural credit and its impact on the productivity of certain cereals in Togo", Emerging Markets Finance and Trade, Vol. 57 No. 12, pp. 1-17, doi: 10.1080/1540496X.2019.1602038.

Ahmad, S., Tariq, M., Hussain, T., Abbas, Q., Elham, H., Haider, I. and Li, X. (2020), "Does Chinese FDI, climate change, and $\mathrm{CO}_{2}$ emissions stimulate agricultural productivity? An empirical evidence from Pakistan”, Sustainability, Vol. 12 No. 18, p. 7485, doi: 10.3390/su12187485.

Ahmed, B. (2018), "Who takes responsibility for the climate refugees?", International Journal of Climate Change Strategies and Management, Vol. 10 No. 1, pp. 5-26, doi: 10.1108/IJCCSM-10-2016-0149.

Ahmed, Z., Zhang, B. and Cary, M. (2021), "Linking economic globalization, economic growth, financial development, and ecological footprint: Evidence from symmetric and asymmetric ARDL", Ecological Indicators, Vol. 121, p. 107060, doi: 10.1016/j.ecolind.2020.107060.

Ahsan, S., Ali, M., Hoque, M., Osman, M., Rahman, M., Babar, M., Begum, S., Rahman, D. and Islam, K. (2010), "Agricultural and environmental changes in Bangladesh in response to global warming", Climate Change and Food Security in South Asia, Springer, pp. 119-134.

Ahsan, F., Chandio, A.A. and Fang, W. (2020), "Climate change impacts on cereal crops production in Pakistan: evidence from cointegration analysis", International Journal of Climate Change Strategies and Management, Vol. 12 No. 2, pp. 257-269, doi: 10.1108/IJCCSM-04-2019-0020.

Alam, K. (2015), "Farmers' adaptation to water scarcity in drought-prone environments: a case study of Rajshahi district, Bangladesh”, Agricultural Water Management, Vol. 148, pp. 196-206, doi: 10.1016/j.agwat.2014.10.011.

Alam, G.M.M., Alam, K. and Mushtaq, S. (2016), "Influence of institutional access and social capital on adaptation decision: empirical evidence from hazard-prone rural households in Bangladesh", Ecological Economics, Vol. 130 No. 130, pp. 243-251.

Alam, A. and Islam, M. (2018), "Impacts of climate change on cropping pattern in coast belt of Bangladesh: study conducted at Paikgacha Upazila of Khulna district", Bangladesh Journal, Vol. 34, pp. 7-10.

Alauddin, M. and Biswas, J. (2014), "Agricultural credit in Bangladesh: trends, patterns, problems and growth impacts”, The Jahangimagar Economic Review, Vol. 25 No. 14, pp. 125-138.

Ali, S., Ying, L., Shah, T., Tariq, A., Ali Chandio, A. and Ali, I. (2019), "Analysis of the nexus of $\mathrm{CO}_{2}$ emissions, economic growth, land under cereal crops and agriculture value-added in Pakistan using an ARDL approach", Energies, Vol. 12 No. 23, p. 4590, doi: 10.3390/en12234590.

Almazroui, M., Saeed, S., Saeed, F., Islam, M.N. and Ismail, M. (2020), "Projections of precipitation and temperature over the South Asian countries in CMIP6", Earth Systems and Environment, Vol. 4 No. 2, pp. 297-320.

Ammani, A.A. (2012), "An investigation into the relationship between agricultural production and formal credit supply in Nigeria", International Journal of Agriculture and Forestry, Vol. 2 No. 1, pp. 46-52.

Ammani, A.A., Jaafaru, A.K., Aliyu, J.A. and Arab, A.I. (2013), "Climate change and maize production: empirical evidence from Kaduna state, Nigeria”, Journal of Agricultural Extension, Vol. 16 No. 1, pp. 1-8.

Anh, N.T., Gan, C. and Anh, D.L.T. (2020), "Does credit boost agricultural performance? Evidence from Vietnam", International Journal of Social Economics, Vol. 47 No. 9, pp. 1203-1221, doi: 10.1108/ IJSE-04-2020-0238.

Arshad, M., Amjathbabu, T.S., Aravindakshan, S., Krupnik, T.J., Toussaint, V., Kachele, H. and Muller, K. (2018), “Climatic variability and thermal stress in Pakistan's rice and wheat systems: a stochastic frontier and quantile regression analysis of economic efficiency", Ecological Indicators, Vol. 89, pp. 496-506, doi: 10.1016/j.ecolind.2017.12.014. 
IJCCSM 14,2

Asumadusarkodie, S. and Owusu, P.A. (2017), "The causal nexus between carbon dioxide emissions and agricultural ecosystem - an econometric approach", Environmental Science and Pollution Research, Vol. 24 No. 2, pp. 1608-1618.

Attiaoui, I. and Boufateh, T. (2019), "Impacts of climate change on cereal farming in Tunisia: a panel ARDL-PMG approach", Environmental Science and Pollution Research, Vol. 26 No. 13, pp. 13334-13345.

Bandara, J.S. and Cai, Y. (2014), "The impact of climate change on food crop productivity, food prices and food security in South Asia", Economic Analysis and Policy, Vol. 44 No. 4, pp. 451-465.

Beggs, P.J. and Walczyk, N. (2008), "Impacts of climate change on plant food allergens: a previously unrecognized threat to human health", Air Quality, Atmosphere and Health, Vol. 1 No. 2, pp. 119-123.

Boansi, D. (2017), "Effect of climatic and non-climatic factors on cassava yields in Togo: agricultural policy implications", Climate, Vol. 5 No. 2, doi: 10.3390/cli5020028.

Chandio, A.A., Gokmenoglu, K.K., Ahmad, M. and Jiang, Y. (2021a), "Towards sustainable rice production in Asia: the role of climatic factors", Earth Systems and Environment, pp. 1-14.

Chandio, A.A., Jiang, Y., Akram, W., Adeel, S., Irfan, M. and Jan, I. (2021b), “Addressing the effect of climate change in the framework of financial and technological development on cereal production in Pakistan”, Journal of Cleaner Production, Vol. 288, doi: 10.1016/j. jclepro.2020.125637.

Chandio, A.A., Jiang, Y. and Rehman, A. (2019), "Energy consumption and agricultural economic growth in Pakistan: is there a nexus?", International Journal of Energy Sector Management, Vol. 13 No. 3, pp. 597-609, doi: 10.1108/IJESM-08-2018-0009.

Chandio, A.A., Jiang, Y., Rehman, A. and Rauf, A. (2020a), "Short and long-run impacts of climate change on agriculture: an empirical evidence from China", International Journal of Climate Change Strategies and Management, Vol. 12 No. 2, pp. 201-221, doi: 10.1108/IJCCSM-05-2019-0026.

Chandio, A.A., Magsi, H. and Ozturk, I. (2020b), "Examining the effects of climate change on rice production: case study of Pakistan”, Environmental Science and Pollution Research, Vol. 27 No. 8, pp. 7812-7822.

Chandio, A.A., Ozturk, I., Akram, W., Ahmad, F. and Mirani, A.A. (2020c), "Empirical analysis of climate change factors affecting cereal yield: evidence from Turkey", Environmental Science and Pollution Research, Vol. 27 No. 11, pp. 11944-11957, doi: 10.1007/s11356-020-07739-y.

Chowdhury, I.U.A. and Khan, M.A.E. (2015), "The impact of climate change on rice yield in Bangladesh: a time series analysis", Russian Journal of Agricultural and Socio-Economic Sciences, Vol. 40 No. 4, pp. 12-28.

Dasgupta, S., Hossain, M.M., Huq, M. and Wheeler, D. (2014), Climate Change, Soil Salinity, and the Economics of High-Yield Rice Production in Coastal Bangladesh, The World Bank.

De Vrese, P., Stacke, T. and Hagemann, S. (2018), "Exploring the biogeophysical limits of global food production under different climate change scenarios", Earth System Dynamics, Vol. 9 No. 2, pp. 393-412.

Deressa, T. and Hassan, R.M. (2009), "Economic impact of climate change on crop production in Ethiopia: evidence from cross-section measures", Journal of African Economies, Vol. 18 No. 4, pp. 529-554.

Eregha, P., Babatolu, J. and Akinnubi, R. (2014), "Climate change and crop production in Nigeria: an error correction modelling approach", International Journal of Energy Economics and Policy, Vol. 4 No. 2, pp. 297-311.

Eshete, Z.S., Mulatu, D.W. and Gatiso, T.G. (2020), " $\mathrm{CO}_{2}$ emissions, agricultural productivity and welfare in Ethiopia", International Journal of Climate Change Strategies and Management, Vol. 12 No. 5, pp. 687-704, doi: 10.1108/IJCCSM-07-2019-0046.

Follett, R. (1993), "Global climate change, US agriculture, and carbon dioxide", Journal of Production Agriculture, Vol. 6 No. 2, pp. 181-190. 
Guntukula, R. (2020), "Assessing the impact of climate change on Indian agriculture: evidence from major crop yields", Journal of Public Affairs, Vol. 20 No. 1, p. e2040.

Haim, D., Shechter, M. and Berliner, P. (2008), "Assessing the impact of climate change on representative field crops in Israeli agriculture: a case study of wheat and cotton", Climatic Change, Vol. 86 Nos 3/4, pp. 425-440.

Hasnisah, A., Azlina, A. and Che, C.M.I. (2019), "The impact of renewable energy consumption on carbon dioxide emissions: empirical evidence from developing countries in Asia", International Journal of Energy Economics and Policy, Vol. 9 No. 3, pp. 135-143.

Hossain, M.S., Qian, L., Arshad, M., Shahid, S., Fahad, S. and Akhter, J. (2019), "Climate change and crop farming in Bangladesh: an analysis of economic impacts", International Journal of Climate Change Strategies and Management, Vol. 11 No. 3, pp. 424-440, doi: 10.1108/IJCCSM-04-20180030.

Hossain, M., Zahid, A., Arifunnahar, M. and Siddique, M. (2019), "Effect of brick kiln on arable land degradation, environmental pollution and consequences on livelihood of Bangladesh", Journal of Science Technology and Environment Informatics, Vol. 6 No. 2, pp. 474-488.

Huq, N., Huge, J., Boon, E.E. and Gain, A.K. (2015), "Climate change impacts in agricultural communities in rural areas of coastal Bangladesh: a tale of many stories", Sustainability, Vol. 7 No. 7, pp. 1-24.

Hussain, S.G. (2011), Assessing Impacts of Climate Change on Cereal Production and Food Security in Bangladesh, Springer, Dordrecht, doi: 10.1007/978-90-481-9516-9_28.

Inumula, K.M., Singh, S. and Solanki, S. (2020), "Energy consumption and agricultural economic growth nexus: evidence from India", International Journal of Energy Economics and Policy, Vol. 10 No. 6, pp. 545-552.

IPCC (2007), "Climate change: impacts, adaptation and vulnerability", Contribution of Working Group II to the Fourth Assessment Report of the Intergovernmental Panel on Climate Change, Cambridge University Press, Cambridge.

IPCC (2014), "Climate change 2014: synthesis report", in Meyer, L.A. (Ed.), Contribution of Working Groups I, II and III to the Fifth Assessment Report of the Intergovernmental Panel on Climate Change, CoreWriting Team Pachauri. IPCC, Geneva, Switzerland, p. 151.

Iqbal, K. and Siddique, A. (2015), "The impact of climate change on agricultural productivity: evidence from panel data of Bangladesh", The Journal of Developing Areas, Vol. 49 No. 6, pp. 89-101.

Islam, T. and Nurseybray, M. (2017), "Adaptation to climate change in agriculture in Bangladesh: the role of formal institutions", Journal of Environmental Management, Vol. 200, pp. 347-358, doi: 10.1016/j.jenvman.2017.05.092.

Khan, A., Ali, S., Shah, S.A., Khan, A.A. and Ullah, R. (2019), "Impact of climate change on maize productivity in Khyber Pakhtunkhwa, Pakistan”, Sarhad Journal of Agriculture, Vol. 35 No. 2, pp. 320-662.

Mackay, A.W. (2008), "Climate change 2007: impacts, adaptation and vulnerability. Contribution of working group II to the fourth assessment report of the intergovernmental panel on climate change", Journal of Environmental Quality, Vol. 37 No. 6, pp. 2407-2407.

Masum, S.J.H. and Hasan, M.M. (2013), "Climate change impact on food sovereignty in Bangladesh", Retrieved April 2, 2015.

Mendelsohn, R., Nordhaus, W.D. and Shaw, D. (1999), "The impact of global warming on agriculture: a Ricardian analysis: reply", American Economic Review, Vol. 89 No. 4, pp. 1046-1048.

MoA (2017), "Agricultural statistics. Ministry of Agriculture (MoA), government of Bangladesh", available at: https://moa.gov.bd/site/page/4fb627c0-d806-4a7e-a1cd-b67d4bc85159/BangladeshAgriculture-at-a-Glance

Molua, E.L. (2009), "An empirical assessment of the impact of climate change on smallholder agriculture in Cameroon”, Global and Planetary Change, Vol. 67 Nos 3/4, pp. 205-208. 
IJCCSM 14,2

Ochieng, J., Kirimi, L. and Mathenge, M.K. (2016), "Effects of climate variability and change on agricultural production: the case of small-scale farmers in Kenya", Njas: Wageningen Journal of Life Sciences, Vol. 77 No. 1, pp. 71-78, doi: 10.1016/j.njas.2016.03.005.

Omoregie, O.K., Ikpesu, F. and Okpe, A.E. (2018), "Credit supply and rice output in Nigeria: empirical insight from vector error correction model approach", International Journal of Economics and Financial Issues, Vol. 8 No. 5, pp. 68-74.

Pesaran, M.H. and Shin, Y. (1998), "An autoregressive distributed-lag modelling approach to cointegration analysis”, Econometric Society Monographs, Vol. 31, pp. 371-413.

Pesaran, M.H., Shin, Y. and Smith, R.J. (2001), "Bounds testing approaches to the analysis of level relationships", Journal of Applied Econometrics, Vol. 16 No. 3, pp. 289-326.

Pickson, R.B., He, G., Ntiamoah, E.B. and Li, C. (2020), "Cereal production in the presence of climate change in China", Environmental Science and Pollution Research, Vol. 27 No. 36, pp. 45802-45813, doi: 10.1007/s11356-020-10430-x.

Praveen, B. and Sharma, P. (2019), "A review of literature on climate change and its impacts on agriculture productivity”, Journal of Public Affairs, Vol. 19 No. 4, p. e1960.

Qureshi, M.I., Awan, U., Arshad, Z., Rasli, A.M., Zaman, K. and Khan, F. (2016), "Dynamic linkages among energy consumption, air pollution, greenhouse gas emissions and agricultural production in Pakistan: sustainable agriculture key to policy success", Natural Hazards, Vol. 84 No. 1, pp. 367-381.

Raifu, I.A. and Aminu, A. (2019), "Financial development and agricultural performance in Nigeria: what role do institutions play?", Agricultural Finance Review, Vol. 80 No. 2, pp. 231-254, doi: 10.1108/ AFR-06-2018-0045.

Rehman, A., Ozturk, I. and Zhang, D. (2019), "The causal connection between $\mathrm{CO}_{2}$ emissions and agricultural productivity in Pakistan: empirical evidence from an autoregressive distributed lag bounds testing approach”, Applied Sciences, Vol. 9 No. 8, p. 1692.

Reilly, J., Tubiello, F., McCarl, B. and Melillo, J. (2001), "Climate change and agriculture in the United States", Climate Change Impacts on the United States: US National Assessment of the Potential Consequences of Climate Variability and Change: Foundation, pp. 379-403.

Rosenzweig, C., Iglesius, A., Yang, X.B., Epstein, P.R. and Chivian, E. (2001), "Climate change and extreme weather events; implications for food production, plant diseases, and pests", Global Change and Human Health.

Ruttan, V.W. (2002), "Productivity growth in world agriculture: sources and constraints", Journal of Economic Perspectives, Vol. 16 No. 4, pp. 161-184.

Sarker, M.A.R., Alam, K. and Gow, J. (2012), "Exploring the relationship between climate change and rice yield in Bangladesh: an analysis of time series data", Agricultural Systems, Vol. 112 No. 112, pp. 11-16.

Sarker, M.A.R., Alam, K. and Gow, J. (2014), "Assessing the effects of climate change on rice yields: an econometric investigation using Bangladeshi panel data", Economic Analysis and Policy, Vol. 44 No. 4, pp. 405-416.

Sarkodie, S.A. and Owusu, P.A. (2017), "The relationship between carbon dioxide, crop and food production index in Ghana: by estimating the long-run elasticities and variance decomposition", Environmental Engineering Research, Vol. 22 No. 2, pp. 193-202.

Shahbaz, M., Shahbaz Shabbir, M. and Sabihuddin Butt, M. (2013), "Effect of financial development on agricultural growth in Pakistan: new extensions from bounds test to level relationships and granger causality tests", International Journal of Social Economics, Vol. 40 No. 8, pp. 707-728, doi: 10.1108/IJSE-01-2012-0002.

Shahid, S. (2011), "Impact of climate change on irrigation water demand of dry season Boro rice in northwest Bangladesh", Climatic Change, Vol. 105 Nos 3/4, pp. 433-453.

Shahid, S., Harun, S.B. and Katimon, A. (2012), "Changes in diurnal temperature range in Bangladesh during the time period 1961-2008”, Atmospheric Research, Vol. 118, pp. 260-270. 
Sikder, R. and Xiaoying, J. (2014), “Climate change impact and agriculture of Bangladesh”, Journal of Environment and Earth Science, Vol. 4 No. 1, pp. 35-40.

Sossou, S., Igue, C.B. and Diallo, M. (2020), "Impact of climate change on cereal yield and production in the Sahel: case of Burkina Faso", Asian Journal of Agricultural Extension, Economics and Sociology, Vol. 37 No. 4, pp. 1-11.

Voortman, R.L., Bgjs, S. and Jwa, L. (1999), Climate Change and Global Agricultural Potential: A Case Study of Nigeria, Sow Vu.

Wang, J., Mendelsohn, R., Dinar, A., Huang, J., Rozelle, S. and Zhang, L. (2009), "The impact of climate change on China's agriculture", Agricultural Economics, Vol. 40 No. 3, pp. 323-337.

Wang, J., Vanga, S.K., Saxena, R., Orsat, V. and Raghavan, V. (2018), "Effect of climate change on the yield of cereal crops: a review", Climate, Vol. 6 No. 2, p. 41.

Warsame, A.A., Sheik-Ali, I.A., Ali, A.O. and Sarkodie, S.A. (2021), "Climate change and crop production nexus in Somalia: an empirical evidence from ARDL technique", Environmental Science and Pollution Research, Vol. 28 No. 16, pp. 19838-19850, doi: 10.1007/s11356-020-11739-3.

WB (2019), "The world bank (2019), "population growth (annual\%)-Bangladesh", available at: https:// data.worldbank.org/indicator/SP.POP.GROW?locations5BD

WDI (2017), "World development indicators", available at: http://data.worldbank.org/

Yawson, D.O., Mulholland, B., Ball, T., Adu, M.O., Mohan, S. and White, P.J. (2017), "Effect of climate and agricultural land use changes on UK feed barley production and food security to the 2050s", Land, Vol. 6 No. 4, pp. 1-14, doi: 10.3390/land6040074.

Yazdi, S.K. and Khanalizadeh, B. (2014), "The financial development and agriculture growth in Iran: ARDL approach", Proceedings of the 5th International Conference on Development, Energy, Environment, Economics, Recent Advances in Energy, Environment and Financial Planning, pp. 335-342.

Zakaria, M., Jun, W. and Khan, M.F. (2019), "Impact of financial development on agricultural productivity in South Asia", Agricultural Economics, Vol. 65 No. 5, pp. 232-239.

Zhai, S., Song, G., Qin, Y., Ye, X. and Lee, J. (2017), "Modeling the impacts of climate change and technical progress on the wheat yield in inland China: an autoregressive distributed lag approach", PloS One, Vol. 12No. 9, p. e0184474.

Ziska, L., Crimmins, A., Auclair, A., DeGrasse, S., Garofalo, J., Khan, A., Loladze, I., de León, A.P., Showler, A. and Thurston, J. (2016), "Ch. 7: food safety, nutrition, and distribution", The Impacts of Climate Change on Human Health in the United States: A Scientific Assessment, pp. 189-216. 
IJCCSM

14,2

\section{4}

Figure A1.

Visual plot of study variables
Figure A2.

Plot of CUSUM test

\section{Appendix}

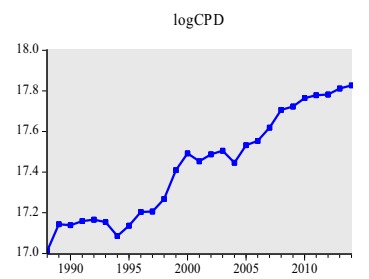

(a)

$\log \mathrm{CO} 2 \mathrm{e}$

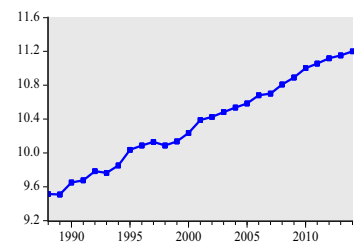

(d)

$\log \mathrm{EC}$

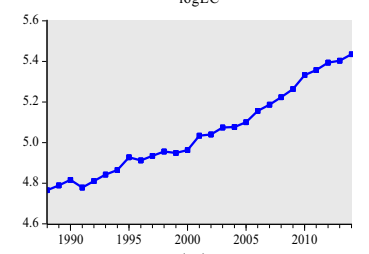

(g)

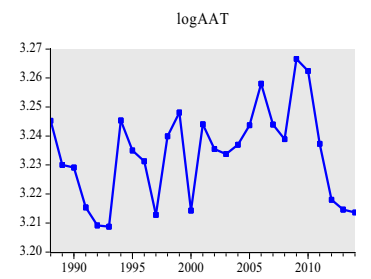

(b)

$\log \mathrm{CCA}$

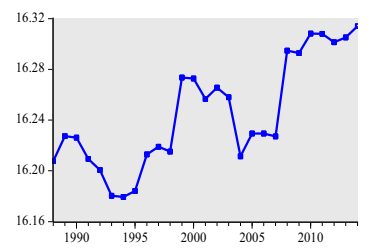

(e)

$\operatorname{logRLF}$

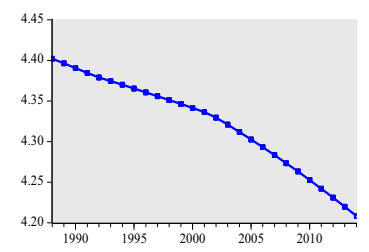

(h)

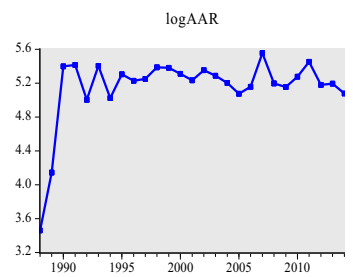

(c)

$\log \mathrm{FD}$

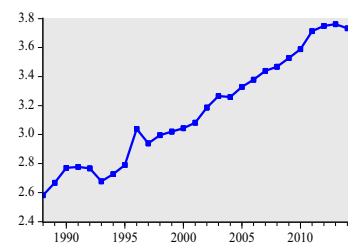

(f)
Notes: (a) $\log$ of cereal production; (b) log of average annual temperature; (c) $\log$ of average annual rainfall, (d) log of carbon dioxide (CO2e);(e) log of cereal cropped area; (f) log of financial development; (g) log of energy consumption;(h) log of rural labor force

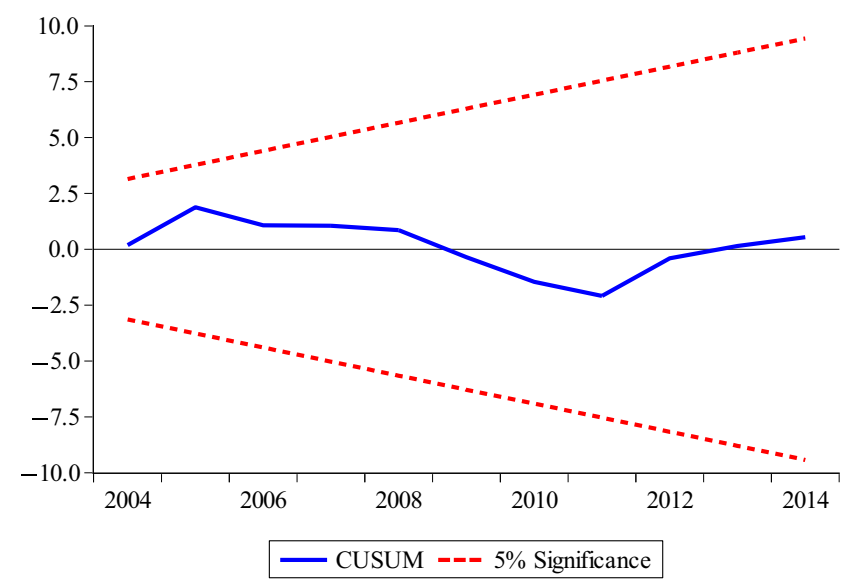




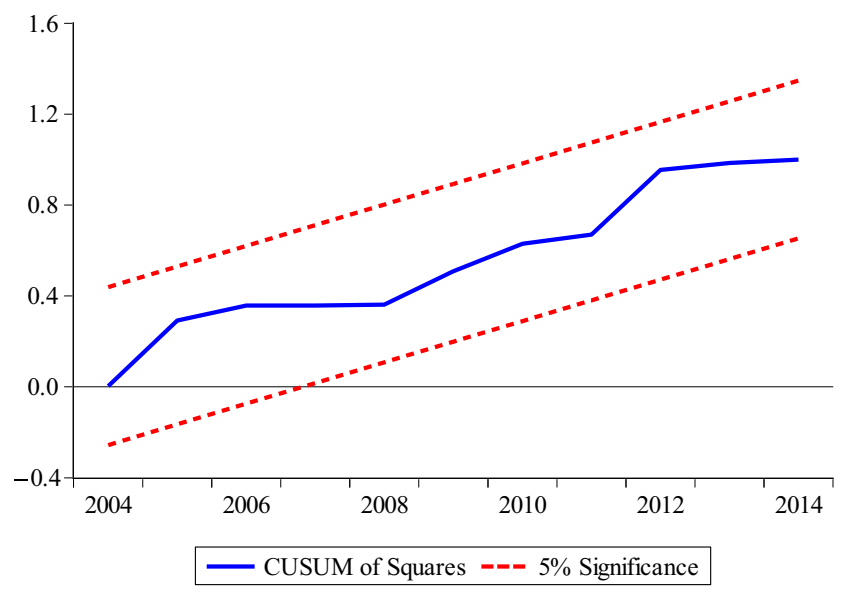

Impacts of climate change on cereal production

Figure A3.

Plot of CUSUM of squares test

\begin{tabular}{lll}
\hline Variables & Unit & Sources \\
\hline Cereal production & metric tons & WDI \\
Average annual temperature & degree celsius & CCKPWB \\
Average annual rainfall & millimeter (mm) & CCKPWB \\
Carbon dioxide & $\mathrm{kt}$ & WDI \\
Cereal cropped area & hectares & WDI \\
Domestic credit to private sector & $\%$ of GDP & WDI \\
Energy use per capita & kg of oil equivalent & WDI \\
Rural population & $\%$ of total population & WDI
\end{tabular}

Note: WDI denotes the World Development Indicators and CCKPWB represents the Climate Change Knowledge Portal of World Bank

Table A1.

Description of the selected study variables 
IJCCSM

14,2

146
岳

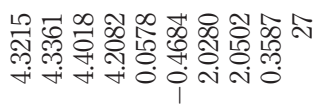

के

Table A2.

Descriptive statistics and correlation analysis
ஊ워

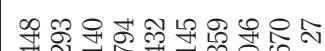

令

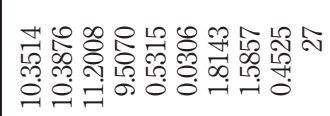

산

0

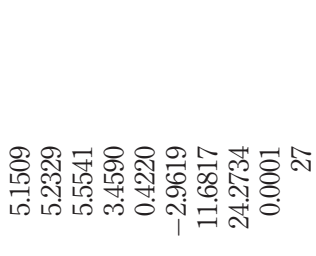

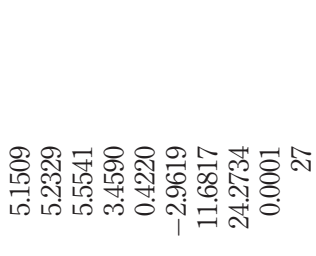

(1)

安

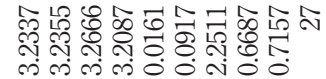

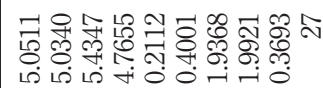

$\rightarrow \quad 40$

으음

\&

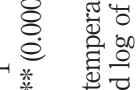

菅 즐

官

8ิ8

é

*

춘

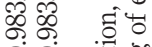

$\circ 0$

ริㅇํㅇํㅇ

焉

業菩焉

告论

o.

응. 쥰

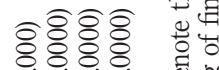

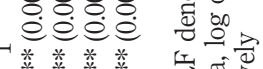

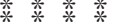

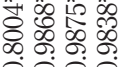

0000

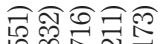

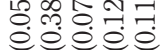

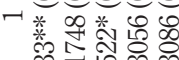

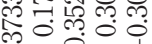

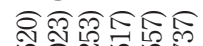

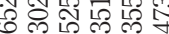

¿巳e巳e

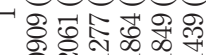
융규면

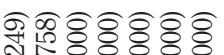

๗.

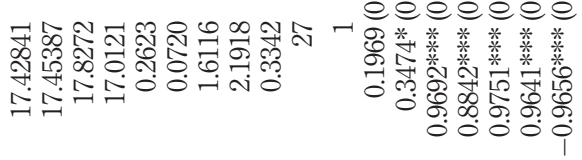

:

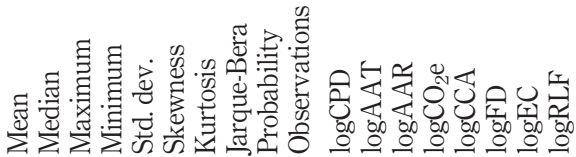

क्षे

유 융

要

되웡

응 흉

손ㄷㅇ

00

o.

s.

월

으몽ㅎㅇ

द्याँच

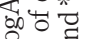

$\therefore$ 응

ㄴ.

藩

돌

을

으르

$\because 00$

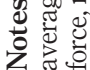

जिष्ठ 


\begin{tabular}{|c|c|c|c|c|c|}
\hline No. of CE(s) & Trace statistic value & Prob. & Max-eigen statistic value & Prob. & clim \\
\hline None & $452.3480^{* * *}$ & 0.0000 & $146.0719 * * *$ & 0.0000 & C1 \\
\hline At most 1 & $306.2761^{* * * *}$ & 0.0000 & $99.7662^{* * *}$ & 0.0000 & \\
\hline At most 2 & $206.5099 * * *$ & 0.0000 & $74.7951^{* * *}$ & 0.0000 & \\
\hline At most 3 & $131.7148^{* * * *}$ & 0.0000 & $51.7915^{* * * *}$ & 0.0002 & \\
\hline At most 4 & $79.92320 * * *$ & 0.0000 & $37.7760 * * *$ & 0.0018 & -4 \\
\hline At most 5 & $42.14719 * * *$ & 0.0012 & $27.0966^{* * *}$ & 0.0064 & \\
\hline At most 6 & 15.05051 & 0.0582 & 13.2251 & 0.0725 & \\
\hline At most 7 & 1.825362 & 0.1767 & 1.8253 & 0.1767 & Table A \\
\hline \multicolumn{5}{|c|}{ Note: $* * *$ shows the significance at $1 \%$} & \\
\hline
\end{tabular}

\begin{abstract}
About the authors
Dr Abbas Ali Chandio is an Associate Professor at the College of Economics, Sichuan Agricultural University. He has obtained his PhD degree in Rural Finance from Sichuan Agricultural University, Chengdu, China, in 2018. His research interest lies in several fields of economics. He has published more than 100 research articles in International Journals. His highest impact factor journal publications included Journal of Cleaner Production, Technology in Society, Environmental Science and Pollution Research and International Journal of Climate Change Strategies and Management.

Professor Yuansheng Jiang is a Dean of the College of Economics, Sichuan Agricultural University, Chengdu, China. He obtained his $\mathrm{PhD}$ degree from the University of Bonn, Germany. He has an attractive publication record in domestic and international journals. His research is mainly focused on Rural Finance and Insurance, Development Economic Theory and Policy, etc. Yuansheng Yuansheng Jiang is the corresponding author and can be contacted at: yjiang@sicau.edu.cn

Dr Tehreem Fatima is currently working as an International Postdoctoral Research Fellow at Asian Demographic Research Institute China. Her main research area is Energy and Environmental Economics. She has published several SSCI and SCI research articles in reputable journals, including the Journal of Environmental Planning of Management, Environment, Development and Sustainability and Environmental Science and Pollution Research.

Dr Fayyaz Ahmad is serving as a full-time faculty member at the School of Economics, Lanzhou University. His research is mainly focused on Environmental and Energy Economics. He has published more than 50 research articles in International Journals. His highest impact factor journal publications included Journal of Cleaner Production, Science of the total environment, Resources Policy and Ecological Indicators.

Dr Munir Ahmad is presently working as an International Postdoctoral Research Fellow at the School of Economics, Zhejiang University, China. He has acquired his $\mathrm{PhD}$ in Management Science and Engineering from North China Electric Power University, Beijing, China. His mainstream research includes Energy and Environmental Economics, Urban Environment and Economy, Renewable Adoption Behavior and Health Psychology and Economics. He has published original research in reputed international journals, including Cleaner Production, Science of the Total Environment, Environmental Research, Sustainable Production and Consumption and Environmental Science and Pollution Research.

Dr Jiajia Li is an Assistant Researcher at Sichuan Agricultural University. She was graduated from a joint $\mathrm{PhD}$ program of Southwestern University of Finance and Economics (China) and Goettingen University (Germany) in 2017. She was a visiting scholar at Duke Kunshan University and Siena University in 2017 and 2019, respectively. Her research interests include Energy and Environmental Economics. She has published a couple of articles in international journals such as Energy Policy and Asian Development Review.
\end{abstract}

For instructions on how to order reprints of this article, please visit our website:

www.emeraldgrouppublishing.com/licensing/reprints.htm

Or contact us for further details: permissions@emeraldinsight.com 